\title{
Phytochemical Evaluation of Polyherbal Formulation of Clinacanthus nutans and Elephantopus scaber to Identify Flavonoids
}

\author{
Muhammad Shahzad Aslam*, Muhammad Syarhabil Ahmad, Awang Soh Mamat
}

\section{Muhammad Shahzad Aslam*, Muhammad Syarhabil Ahmad, Awang Soh Mamat}

School of Bioprocess Engineering, Universiti Malaysia Perlis, Kompleks Pusat Pengajian Jejawi 3 (KPPJ3), Kawasan Perindustrian Jejawi, 02600, Arau, Perlis, MALAYSIA.

\section{Correspondence}

Muhammad Shahzad Aslam, School of Bioprocess Engineering, Universiti Malaysia Perlis, Kompleks Pusat Pengajian Jejawi 3 (KPPJ3), Kawasan Perindustrian Jejawi, 02600, Arau, Perlis, MALAYSIA.

Phone numbers: +60193009674

Email: aslammuhammadshahzad@ gmail.com

DOI : 10.5530/pj.2016.6.4

Article Available online http://www.phcogj.com/v8/i6

Copyright

(C) 2016 Phcog.Net. This is an openaccess article distributed under the terms of the Creative Commons Attribution 4.0 International license.

\begin{abstract}
Background: Modern healthcare system recognizes herbal medicine as a form of alternative medicine and also identify as holistic approach. Everyone in life experiences different kind of wound.Clinacanthus nutans and Elephantopus scaber are well known traditional wound healing herbs. Objective: To develop a new polyherbal formulation in the treatment of wound and identify flavonoid by means of chromatography, chemical method and spectroscopic method. Preliminary phytochemical and fluorescent evaluation of Clinacanthus nutans, Elephantopus scaber and herb-herb combination. Methods and Material: Preliminary phytochemical and fluorescent evaluation of Clinacanthus nutans, Elephantopus and polyherbal formulation of both herb by chemical method. Identification of flavonoids by thin layer chromatography and fourier transform infrared spectroscopy. Results: Flavonoids have found inside polyherbal formulation by comparing the colour change after chemical analysis, Fluorescence analysis, retention time by thin layer chromatography and functional groups by fourier transform infrared spectroscopy. Conclusions: Flavonoids may responsible for its activity as wound healing. It may work with other bioactive compounds as synergistic effect.

Key words: Clinacanthus nutans, Elephantopus scaber, Polyherbal formulation, Herb-Herb combination, Flavonoids, Wound healing.
\end{abstract}

\section{INTRODUCTION}

The trend of using herbal medicines has increased in a tremendous way in the last decade. As a result, World health Organization (WHO) has taken a broader step of including Phytotherapy. Herb-herb combinations have used in Chinese, Ayurveda and Malaysian traditional medicine practice for many years. $^{1-3}$ Many commercial and non-commercial polyhedral formulations exist in different part of World. Scientific evidence such as pharmacognostic evaluation, phytochemical study, and pharmacological evaluation Lacks in most of the polyherbalformulation. ${ }^{1}$ Clinacanthus nutans Lindau is known as snake grass belonging to the Acanthaceae family. This plant has diverse and potential medicinal uses in traditional herbal medicine for treating skin rashes, insects and snake bites, lesions caused by herpes simplex virus, diabetes, and gout in Malaysia, Indonesia, Thailand, and China. ${ }^{4}$ Elephantopus scaber Linn. is known as Prickly-leaves elephant's foot, tutup bumi in Malay or di dan tou in Chinese. It has been used in traditional medicine to stimulate diuresis, reduce fever and eliminate bladder stones, as well as to treat nephritis, edema, dampness, chest pain, pneumonia, scabies, arthralgia and leukemia. ${ }^{5,6}$ It was used in number of poly herbal formulations. The selection of both herb was based upon its activity as wound healing.
The objective of our study was development of a new formulation and phytochemical evaluation of new herbal formulation.

\section{METHOD AND MATERIAL}

Plant Material

The leaves of Clinacanthus nutans and Elephantopus scaber were collected from Institute Of Sustainable Agro technology, Sg. Chuchuh, University Malaysia Perlis (UniMAP) and washed using clean water. After that, the leaves were dried inside a dryer at the temperature of $35-40^{\circ} \mathrm{C}$ for two days. Once dried, the leaves were grinded into fine powder by using mechanical grinder.

\section{Preparation of Plant Extract}

Soxhlet extraction was used in this experiment to extract the herbs. For Soxhlet extraction, a powder sample is weighted approximately $10 \mathrm{~g}$ for each herb and put into the extract chamber of the Soxhlet extractor. In each running experiment, $100 \mathrm{ml}$ of aqueous ethanol $50 \%$ was used as solvent for 12 hour extraction. The extract solution was then evaporated by using rotary evaporator to remove the solvent in the extract solution and dried in oven at $35-40^{\circ} \mathrm{C}$ for 12 hour. In order to study the synergistic effects of the herb pairs, a powdered mixture containing equal proportions of two herbs ( $5 \mathrm{~g}$ each) was extracted 
according to the above method. The final samples were stored at $4^{\circ} \mathrm{C}$ until it analysed and the percentage of yield was calculated by using Equation

$$
\mathrm{Y}_{\text {extract }}=\mathrm{m}_{\text {extract }} / \mathrm{m}_{\text {herb }} \times 100
$$

where $\mathrm{m}_{\text {extract }}$ is the crude extract mass $(\mathrm{g})$ and $\mathrm{m}_{\text {herb }}$ is the extracted herb mass.The extract was fractionated using different solvents viz. hexane, chloroform, ethyl acetate, n-butanol and water. The supernatant was filtered using Whatman No. 1 sheet, pooled and concentrated using vacuum rotary evaporator. The concentrated solutions were then lyophilized to get the dry form of respective fractions.

\section{Chemicals}

Ethyl acetate, ethanol, toluene, chloroform, methanol, anisaldehyde (Fisher Scientific, UK), Sulphuric acid, Hydrochloric acid, Ammonia, glacial acetic acid, Ascorbic acid (HmbG), Thin layer chromatography silica gel 60 F254 precoated plates, Formic acid, (Merck, Darmstadt, Germany), ferric chloride, sodium hydroxide $(\mathrm{NaOH})$ (Sigma-Aldrich, USA).

\section{Phytochemical test}

Phytochemical analysis for each sample's crude extract ware carried out according to the standard procedure methods. ${ }^{7.8}$

\section{Test for alkaloids}

$1 \mathrm{~mL}$ of crude extract was mixed with $5 \mathrm{~mL}$ of diluted hydrochloride acid (HCL) and was placed in a water bath at $60^{\circ} \mathrm{C}$ for 15 minutes. $1 \mathrm{~mL}$ of Wagner's reagent was added into $1 \mathrm{~mL}$ of filtered suspension.

Appearance of reddish-brown precipitate showed the presence of alkaloids.

\section{Test for cardiac glycoside}

Crude extract was treated with $1 \mathrm{~mL}$ of glacial acetic acid diluted (3\%) ferric chloride $\left(\mathrm{FeCl}_{2}\right)$ follow by adding concentrated sulphuric acid $\left(\mathrm{H}_{2} \mathrm{SO}_{4}\right)$ at the side of the test tube. The formation of brown ring indicated the presence of cardiac glycoside.

\section{Test for flavonoid}

Intense yellow color formed when $1 \mathrm{~mL}$ of sodium hydroxide $(\mathrm{NaOH})$ solution was added into $1 \mathrm{~mL}$ of crude extract. The yellow color turned colorless upon addition of diluted $\mathrm{H}_{2} \mathrm{SO}_{4}$, which indicated the presence of flavoniod.

\section{Test for phenolic compounds and tannin}

$2 \mathrm{~mL}$ of crude extract in test tube and add $3 \% \mathrm{FeCl}_{2}$ drop by drop. Appearance of bluish black precipitate indicates the presence of phenolic compounds and tannin.

\section{Test for saponin}

$0.5 \mathrm{~mL}$ ofcrude extract was diluted with $5 \mathrm{~mL}$ of distill water. The suspension was shaken vigorously for a few minutes. Development of foam which is able to persist for 10 minutes shown the presence of saponin.

\section{Salkowski Test for phytosterols}

Crude extract was treated with $0.5 \mathrm{~mL}$ of chloroform, add $1 \mathrm{~mL}$ of concentrated $\mathrm{H}_{2} \mathrm{SO}_{4}$ from the sides of test tube. Appearance of of reddish brown color in chloroform layerindicates the prescene of phytosterol.

\section{Liebermann-Burchard's Test for triterpenoid}

$0.5 \mathrm{~mL}$ of crude extract was treated with few drops of acetic anhydride, boil and cool. $1 \mathrm{~mL}$ of concentrated $\mathrm{H}_{2} \mathrm{SO}_{4}$ was added from the sides of test tube. Formations of reddish brown at the junction of two layer and formation of deep red color confirm the presence of terpenoid.

\section{Fluorescence analysis}

Fluorescence is an important phenomenon exhibited by various chemical constituents present in plant material. If the substances themselves are not fluorescent they may often be converted into fluorescent derivatives by reagents, hence some crude drugs are often assessed qualitatively in this way and it is an important parameter of pharmacognostical evaluation ${ }^{9}$

\section{TLC Analysis for flavonoids}

About $2 \mu \mathrm{g}$ of extracts was loaded on TLC plates (Merck). The plates were developed in toluene: chloroform: methanol (4:4:1, v/v/v) to separate flavonoid compounds of the extracts. The developed plate was air dried. Then anisaldehyde sulfuric acid was sprayed on the surface of the plate and incubated for $20 \mathrm{~min}$ at $100^{\circ} \mathrm{C}$. The present flavonoid compound of this extracts was detected as blue spot on developed TLC plate. The $\mathrm{R}_{\mathrm{f}}$ value of the bands were also determined. ${ }^{8}$

\section{Fourier Transform Infrared Spectrophotometer}

Fourier Transform Infrared Spectrophotometer (FTIR) is perhaps the most powerful tool for identifying the types of chemical bonds (functional groups) present in compounds. The wavelength of light absorbed is characteristic of the chemical bond as can be seen in the annotated spectrum. By interpreting the infrared absorption spectrum, the chemical bonds in a molecule can be determined. ${ }^{10}$ The sample of each plant specimen was loaded in FTIR spectroscope (PerkimElmer Spectrum 65, USA), with a Scan range from 650 to $4000 \mathrm{~cm}^{-1}$ using Attenuated Total Reflection (ATR) Method. Result were obtain using Perkim Elmer Spectrum version 10.03.06.

\section{RESULTS}

Preliminary phytochemical analysis of newly polyherbal formulation is of significant importance as scientist need to understand the change upon extraction of equal portion of two different medicinal herb (Clinacanthus nutans and Elephantopus scaber). The combined herbal extract possess the bioactive compound of both herb. Results have showed shows the strong presence of Flavonoid, phenol, tannin, saponin, alkaloid. Whereas it possess moderate presence of Triterpenoid, phytosterol, cardiac glycoside. The phytochemical analysis of Clinacanthus nutans shows the strong presence of flavonoids, phenolic compounds, alkaloids and tannin. Whereas it possess moderate presence of triterpenoid and minimum level of phytosterol and cardiac glycoside. The phytochemical analysis of Elephantopus scaber shows the strong presence of phytosterol and saponin. Whereas it possess moderate presence of cardiac glycoside. Flavonoids, phenol, triterpenoid. All the result was based upon the qualitative analysis such as color change after reaction (Table 2).

Fluorescent Analysis of Clinacanthus nutans, Elephantopus scaber and Clinacanthus nutans + Elephantopus scaber were performed by different solvents. Different colours gives an idea about nature of compound inside sample. An interesting observation have found during the evaluation of polyherbal powder that the colour after reaction is similar with the colour after Reaction of reagent with Elephantous scaber. This may be due to dark colour of powder of Elephantopus scaber as compare to Clinacanthus nutans. Clinacanthus nutans is light greenish powder whereas Elephantous scaber powderis dark green in nature.

Fluorescent Analysis identify possible bioactive compounds by observing the colour present inside the sample as mentioned in Table 3.

TLC Analysis of flavonoids of Clinacanthus nutans, Elephantopus scaber, Clinacanthus nutans + Elephantopus scaber and their fractions have confirm the presence of flavonoids. Blue colour spots indicates that flavonoid present inside the sample (Figure 1 and 2). Retention factor shows possible bioactive compound inside the sample (Table 7). 
Table 1: \%age yield of Clinacanthus nutans, Elephantopus scaber and Clinacanthus nutans +Elephantopus scaber

\begin{tabular}{ccc}
\hline Sample & Mass Yield (gm) & Mass Yield (\%) \\
\hline Clinacanthus nutans & $2.50 \mathrm{gm}$ & 25 \\
Elephantopus scaber & $1.8 \mathrm{gm}$ & 18 \\
Clinacanthus nutans + Elephantopus scaber & $2.0 \mathrm{gm}$ & 20
\end{tabular}

Table 2: Phytocehmical analysis of Clinacanthus nutans, Elephantopus scaber and Clinacanthus nutans +Elephantopus scaber

\begin{tabular}{cccc}
\hline Phytochemical Analysis & Clinacanthus nutans & Elephantopus scaber & Clinacanthus nutans + Elephantopus scaber \\
\hline Alkaloids & +++ & - & +++ \\
Cardiac glycoside & + & ++ & ++ \\
Flavonoids & +++ & ++ & +++ \\
Phenol & +++ & ++ & +++ \\
Saponin & - & +++ & +++ \\
Phytosterols & + & +++ & ++ \\
Triterpenoid & ++ & ++ & ++ \\
Tannin & +++ & ++ & +++
\end{tabular}

+++ = High amount; ++ = Moderate amount; + = Minimum amount; - = Absent.

Table 3: Fluorescence analysis of Clinacanthus nutans, Elephantopus scaber and Clinacanthus nutans +Elephantopus scaber

\begin{tabular}{|c|c|c|c|c|c|c|}
\hline \multirow{3}{*}{ Treatment with reagent } & \multicolumn{6}{|c|}{ Fluorescence analysis } \\
\hline & \multicolumn{3}{|c|}{ Ordinary Light } & \multicolumn{3}{|c|}{ U.V. Light (254nm) } \\
\hline & $\begin{array}{l}\text { Clinacanthus } \\
\text { nutans }\end{array}$ & $\begin{array}{c}\text { Elephantopus } \\
\text { scaber }\end{array}$ & Combination & $\begin{array}{c}\text { Clinacanthus } \\
\text { nutans }\end{array}$ & $\begin{array}{l}\text { Elephantopus } \\
\text { scaber }\end{array}$ & Combination \\
\hline Powder as such & Light green & Dark green & Dark green & Brown & Brown & Brown \\
\hline Powder + Water & Turbid & Turbid & Turbid & Brown & Brown & Brown \\
\hline Powder + Ethanol & Greenish & Yellowish green & Yellowish green & Yellowish Brown & Brown & Brown \\
\hline Powder + Methanol & Greenish & Yellowish green & Yellowish green & Dark brown & Light brown & Light Brown \\
\hline Powder $+\mathrm{n}$-hexane & Yellow & White & Yellow & Dark brown & Light brown & Light Brown \\
\hline Powder + Ethyl acetate & Greenish & Yellowish green & Yellowish green & Brown & Reddish orange & Dark Red \\
\hline Powder + Chloroform & Dark green & Yellow & Yellowish green & Dark Brown & Dark Brown & Dark Brown \\
\hline Powder + Acetone & Green & Yellowish green & Green & Dark brown & Reddish orange & Reddish orange \\
\hline Powder + Glacial acetic acid & Yellowish brown & Brown & Yellowish brown & Yellow & Orange & Orange red \\
\hline Powder + Sulphuric acid (10\%) & Light brown & Reddish brown & Reddish brown & Yellow & Dark brown & Reddish brown \\
\hline Powder + Sodium hydroxide (10\%) & Turbid Orange & Clear Orange & Light orange & Dark orange & Orange & Light orange \\
\hline Powder + Sodium hydroxide $(1 \mathrm{~N})$ & Yellow & Brown & Yellowish brown & Yellow & Orange & Orange \\
\hline Powder + Potassium hydroxide (5\%) & Reddish brown & Brown & Light brown & Brown & Brown & Brown \\
\hline Powder + Nitric Acid & Yellow & Orange & Orange & Yellowish Red & Pink Red & Pink Red \\
\hline
\end{tabular}

Table 4: TLC Analysis of flavonoids of Clinacanthus nutans, Elephantopus scaber and Clinacanthus nutans +Elephantopus scaber

\begin{tabular}{ccccc}
\hline Extract & Solvent System & Revealing reagent & No. of spots & Rf Value \\
\hline Clinacanthus nutans & $\begin{array}{c}\text { toluene: chloroform: } \\
\text { methanol (4:4:1, v/v/v) }\end{array}$ & anisaldehyde sulfuric acid & 1 & $\mathbf{0 . 1 3}$ \\
Elephanotopus scaber & $\begin{array}{c}\text { toluene: chloroform: } \\
\text { methanol (4:4:1, v/v/v) } \\
\text { Clinacanthus nutans + Elephanotopus scaber }\end{array}$ & anisaldehyde sulfuric acid & 3 & $0.4, \mathbf{0 . 6 6 , 0 . 9}$ \\
& $\begin{array}{c}\text { toluene: chloroform: } \\
\text { methanol (4:4:1, v/v/v) }\end{array}$ & anisaldehyde sulfuric acid & 2 & $0.7,0.97$ \\
\hline
\end{tabular}


Table 5: TLC Analysis of flavonoids of Clinacanthus nutans + Elephantopus scaber fractions

\begin{tabular}{|c|c|c|c|c|}
\hline $\begin{array}{l}\text { Fractions of Clinacanthus nutans } \\
+ \text { Elephantopus scaber }\end{array}$ & Solvent System & Revealing reagent & No. of spots & Rf Value \\
\hline n-hexane & $\begin{array}{l}\text { toluene: chloroform: } \\
\text { methanol }(4: 4: 1, \mathrm{v} / \mathrm{v} / \mathrm{v})\end{array}$ & anisaldehyde sulfuric acid & 4 & $0.26,0.62,0.80,0.92$ \\
\hline Chloroform & $\begin{array}{l}\text { toluene: chloroform: } \\
\text { methanol }(4: 4: 1, \mathrm{v} / \mathrm{v} / \mathrm{v})\end{array}$ & anisaldehyde sulfuric acid & 4 & $0.21, \mathbf{0 . 5 6}, 0.71,0.90$ \\
\hline Ethylacetate & $\begin{array}{l}\text { toluene: chloroform: } \\
\text { methanol }(4: 4: 1, \mathrm{v} / \mathrm{v} / \mathrm{v})\end{array}$ & anisaldehyde sulfuric acid & 3 & $0.21,0.76,0.97$ \\
\hline n-butanol & $\begin{array}{l}\text { toluene: chloroform: } \\
\text { methanol }(4: 4: 1, \mathrm{v} / \mathrm{v} / \mathrm{v})\end{array}$ & anisaldehyde sulfuric acid & 4 & $0.21, \mathbf{0 . 6 6}, \mathbf{0 . 8 0}, 0.95$ \\
\hline
\end{tabular}

Table 6: Predicted bioactive compounds after Fluorescence analysis under (a) ordinary light and (b) UV-254nm

\begin{tabular}{cc}
\hline Colors seen under ordinary light & Possible bioactive compounds \\
\hline $\begin{array}{c}\text { Greenish, Yellow brown, Yellowish green } \\
\text { Bright Yellow or Pale Yellow }\end{array}$ & $\begin{array}{c}\text { Chlorophyll pigments such as Pheophytin b, Chlorophyll a } \\
\text { 6-hydroxylated flavonols, flavone, some chalcone } \\
\text { glycosides, flavone glycosides }\end{array}$ \\
\hline Colours seen under UV-254nm & (a) \\
\hline Dark brown & Possible bioactive compounds \\
\hline
\end{tabular}

(b)

Table 7: Predicted bioactive compounds after TLC Analysis(16)(17)

\begin{tabular}{cc}
\hline Rf values & Possible flavonoids \\
\hline 0.28 & Luteolin \\
0.62 & Galangin \\
0.39 & Kaempferol \\
0.27 & Quercetin \\
0.13 & Myricetin \\
0.26 & Isorhamnetin \\
0.82 & Apigenin \\
\hline
\end{tabular}

Table 8: Predicted functional group after Fourier Transform Infrared spectroscopy

\begin{tabular}{|c|c|c|}
\hline Samples Prepared & Peak values $(\mathrm{cm}-1)$ & Functional groups \\
\hline Clinacanthus nutans & $3330,2872,1626,1407,1046,879$ & $\begin{aligned} 3500-3200 & =(\mathrm{OH}) \text { Stretching }(\text { alcohol } \\
& \text { and Phenol })\end{aligned}$ \\
\hline & & $2850-2957=(\mathrm{CH})$ Stretching (alkyl) \\
\hline Elephantopus scaber & $\begin{array}{c}3353,2924,2853,1735,1620,1454,1379,1260 \\
1156,1047,882,804,721\end{array}$ & $\begin{array}{c}1585-1626=\text { Aromatic } \\
1620-1680=C=C\end{array}$ \\
\hline Clinacanthus nutans + & $3353,2924,2853,1736,1617,1454,1379,1260,1159,1049,813,721$ & $1850-1650(\mathrm{C}=\mathrm{O})$ \\
\hline Elephantopus scaber & & ( $\mathrm{C}=\mathrm{O}$ conjugation with $\mathrm{C}=\mathrm{C}$, the \\
\hline N-hexane & $3392,2922,2850,1736,1451,1382,1263,1165,1038,720$ & frequency lowered from 1700 to 1650 \\
\hline Chloroform & $3410,2921,2853,1736,1451,1370,1260,1084,1017,797$ & Depending upon number of unsaturation) \\
\hline Ethyl acetate & $3349,2919,1610,1394,1263,1051$ & $1394-1451=(\mathrm{CH})$ Bend \\
\hline Sthutanol & & $1320-1000=\mathrm{C}-\mathrm{O}$ stretch, \\
\hline N-butanol & $3334,2957,2930,2874,1722,1611,1458,1382,1071$ & $1054=$ representing either ether or alcohol \\
\hline Remaning aqueous fractions & $3365,2924,1616,1401,1054$ & $1250=$ carboxylic acid \\
\hline
\end{tabular}




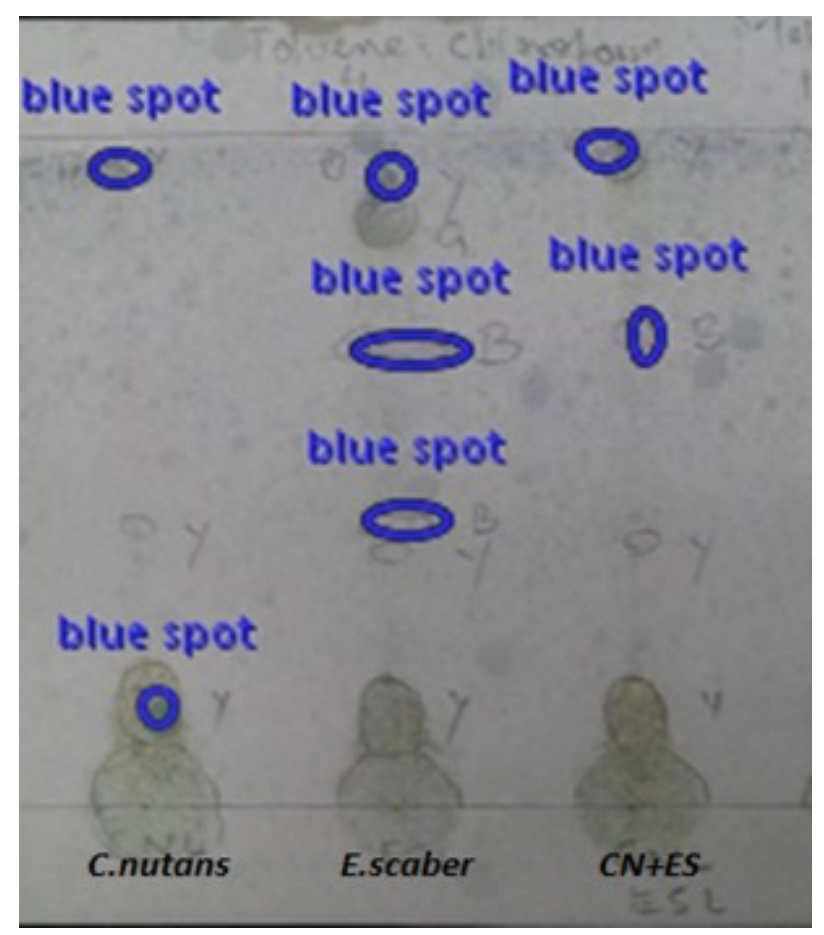

Figure 1: TLC Analysis of flavonoids of Clinacanthus nutans, Elephantopus scaber and Clinacanthus nutans + Elephantopus scaber using reagent.

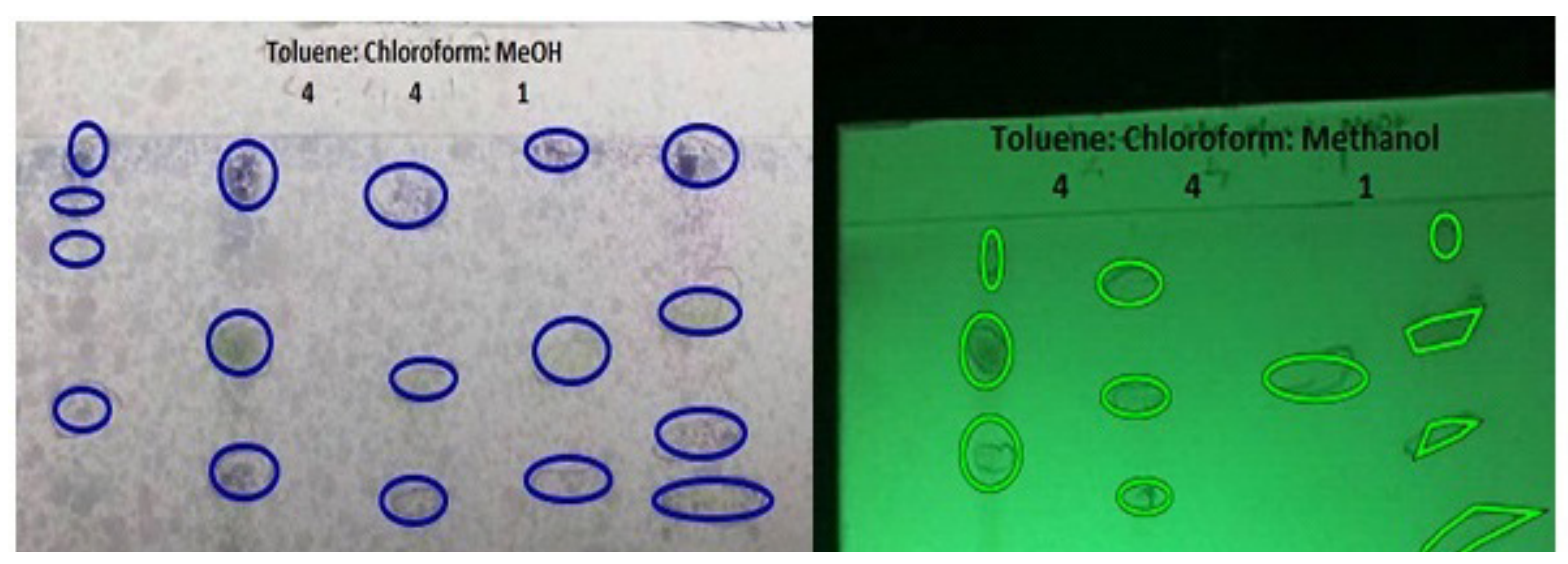

Figure 2: TLC Analysis of flavonoids of Clinacanthus nutans + Elephantopus scaber fractions using reagent and under UV $254 \mathrm{~nm}$ 


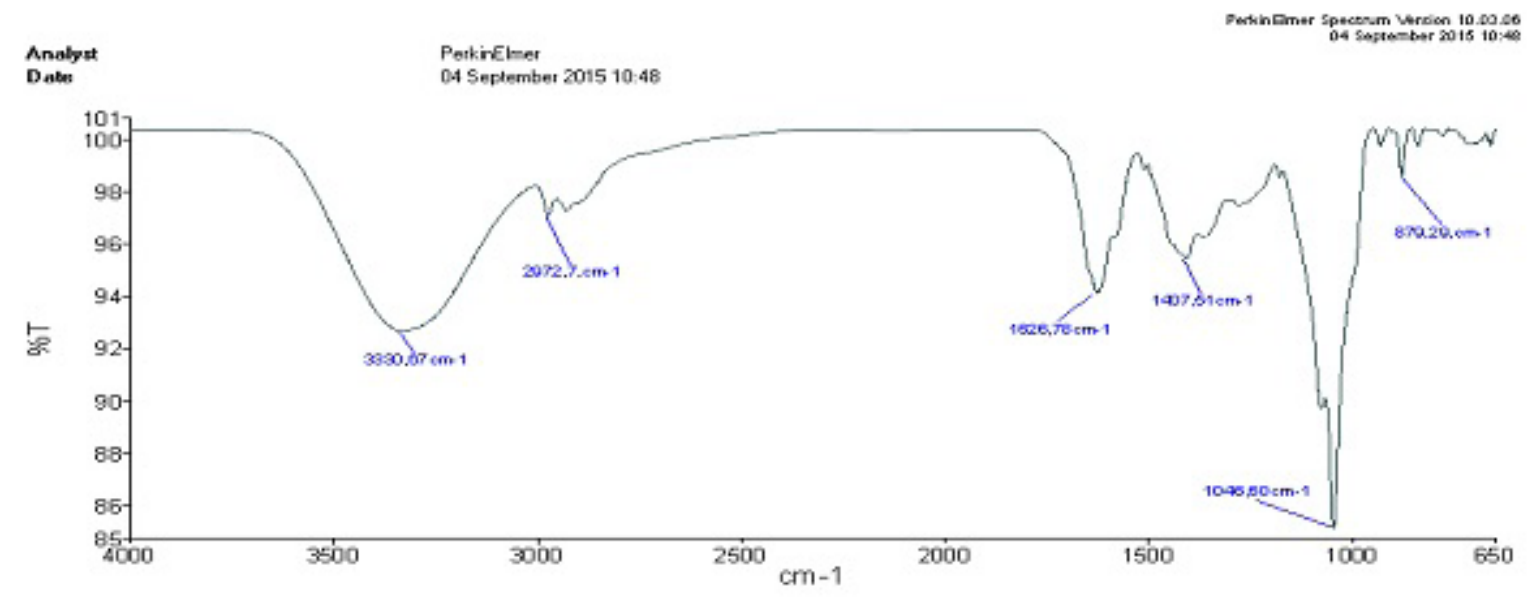

(a)

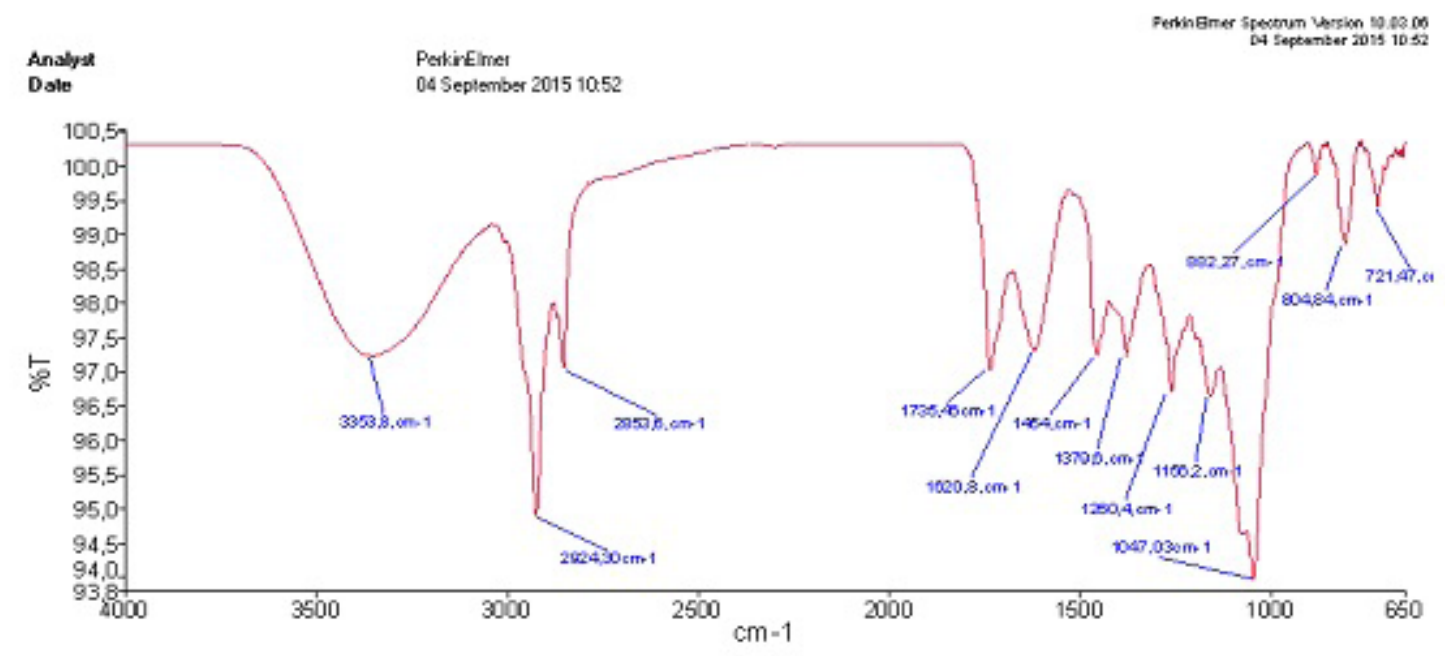

(b)

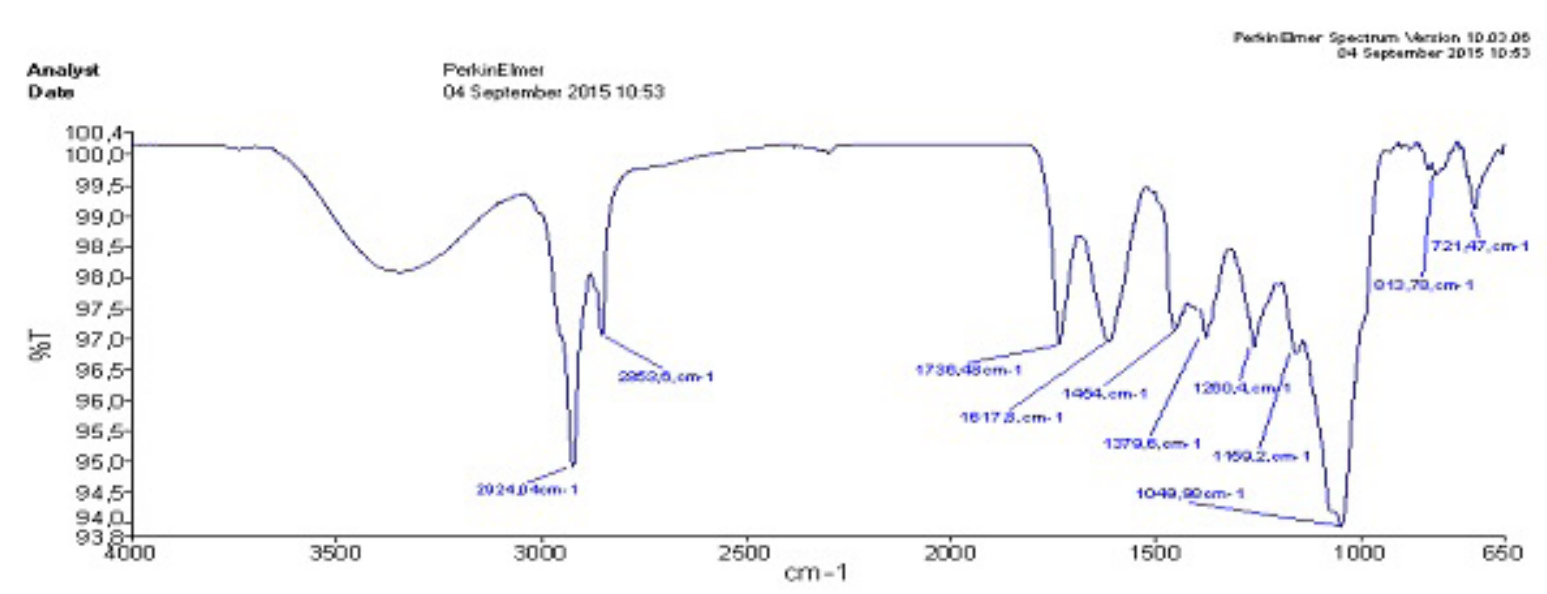

(c)

Figure 3: FTIR spectrum of Clinacanthus nutans, Elephantopus scaber and Clinacanthus nutans + Elephantopus scaber. 


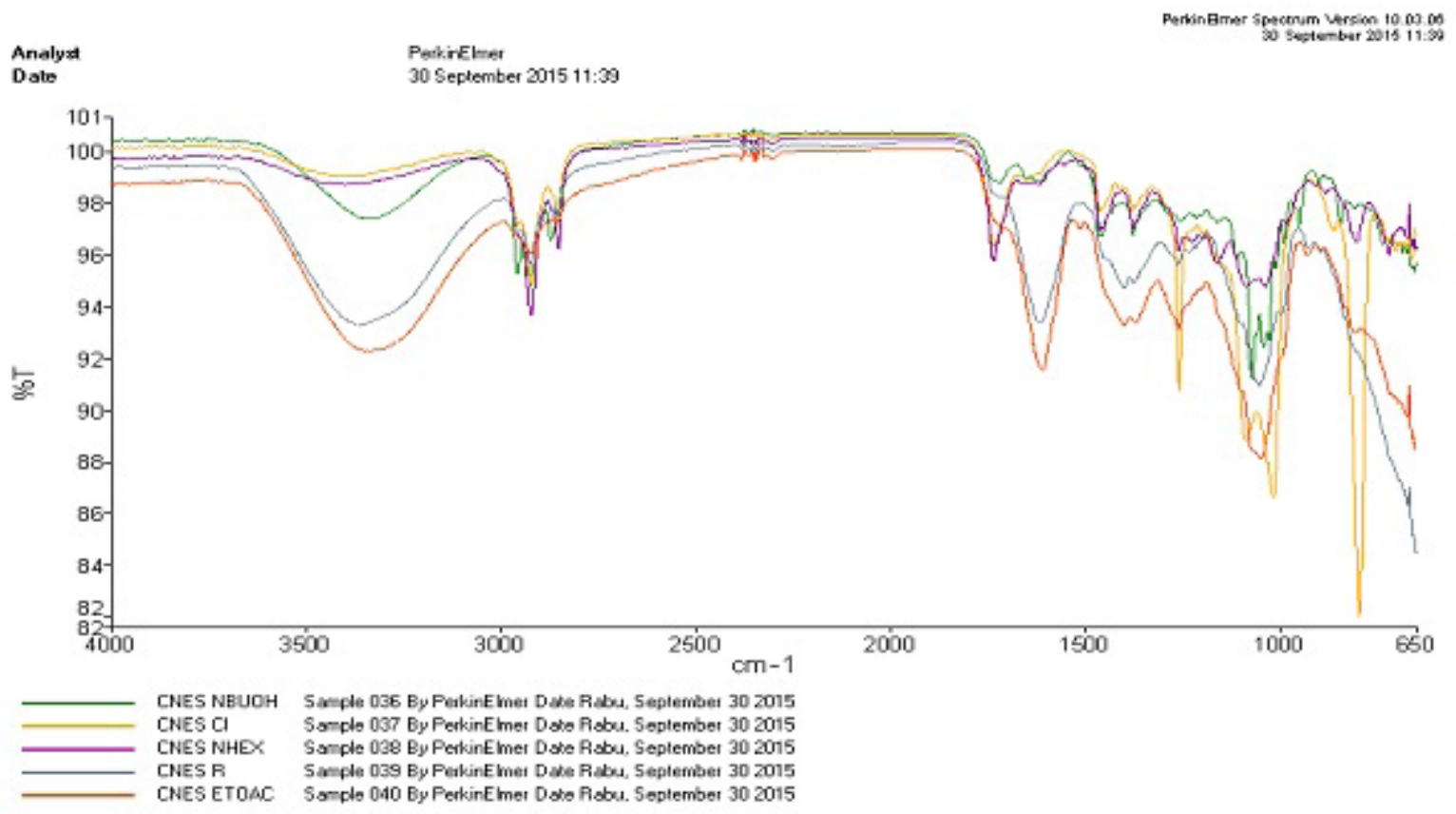

Figure 4: FTIR spectrum of Clinacanthus nutans + Elephantopus scaber fractions.

Fourier Transform Infrared Spectrophotometer (FTIR) identify flavonoid by comparing the bonds (functional groups) present inside the sample as mentioned in Table 8 .

\section{DISCUSSION}

There is a need of time about scientific evaluation of Polyherbal formulation for the future. Development of new herbal formulation has been the success after extensive literature review. The bioactive compound of both medicinal herb present inside polyherbal extract that may result into more powerful wound healing agent. Flavonoids has played as important role as wound healing due to its anti-inflammatory potential through NFאB synthesis inhibition. ${ }^{11,12}$ The literature review suggest that Clinacanthus nutans and Elephantopus scaber has antioxidant properties, which may be responsible and constructive for faster wound healing. ${ }^{13-15}$ Further investigation on new poly herbal formulation in the treatment of wound and isolation of bioactive compounds is currently in progress.

\section{ACKNOWLEDGEMENT}

This research was supported by Universiti Malaysia Perlis (UniMAP) and Ministry of Higher Education Malaysia (Malaysian International Scholarship; Reference no.KPT.B.600-18/3 JLD 6 (31)]).

\section{CONFLICT OF INTEREST}

This is no conflict of interest among authors.

\section{ABBREVIATION USED}

CN: Clinacanthus nutans; ES: Elephantopus scaber ; HCl: Hydrochloroic acid; $\mathrm{H}_{2} \mathrm{SO}_{4}$ : Sulfuric acid ; $\mathrm{FeCl}_{2}$ : ferric chloride ; $\mathrm{NaOH}$ : sodium hydroxide ; FTIR: Fourier Transform Infrared Spectrophotometer ; ATR: Attenuated Total Reflection Method ; TLC: Thin Layer Chromatography; NFkB : Nuclear factor kappa-light-chain-enhancer of activated B cells.

\section{REFERENCES}

1. Che CT, Wang ZJ, Chow MSS, Lam CWK. Herb-herb combination for therapeutic enhancement and advancement: Theory, practice and future perspectives. Molecules. 2013;18(5):5125-41. http://dx.doi.org/10.3390/molecules18055125; PMid:23644978

2. Subramani Parasuraman, Gan Siaw Thing, SAD. Polyherbal formulation concept of ayurveda. Pharmacogn Rev. 2014;8(16):73-80. http://dx.doi.org/10.4103/09737847.134229; PMid:25125878 PMCid:PMC4127824

3. Mohd Fuat a. R, Aidoo KE, Calvert TW, Candlish a. a. G. Mycoflora, Cytotoxicity, and DNA Interaction of Polyherbal Products from Malaysia. Pharm Biol [Internet]. 2006;44(1):23-31. Available from: http://www.scopus.com/inward/record. url?eid=2-s2.0-33644979761\&partnerlD=tZOtx3y1. http://dx.doi.org/10.1080/ 13880200500530500

4. Alam A, Ferdosh S, Ghafoor K, Hakim A, Juraimi AS, Khatib A, et al. Clinacanthus nutans: A review of the medicinal uses, pharmacology and phytochemistry. 2016;9(4):402-9. Available from: http://dx. doi.org/10.1016/j.apjtm.2016.03.011.

5. Ho WY, Ky H, Yeap SK, Rahim RA, Omar AR. Traditional practice, bioactivities and commercialization potential of Elephantopus scaber Linn. J Med Plants Res. 2009;3(13):1212-21.

6. Hiradeve SM, Rangari VD. Elephantopus scaber Linn.: A review on its ethnomedical, phytochemical and pharmacological profile. J Appl Biomed. 2014 Apr [cited 2015 Apr 20];12(2):49-61. Available from: http://www.sciencedirect.com/ science/article/pii/S1214021X14000349

7. HilalT, Alabri A, Hamood A, AI S, Hossain MA, Weli AM, et al. Comparative study of phytochemical screening, antioxidant and antimicrobial capacities of fresh and dry leaves crude plant extracts of Datura mete/L. J King Saud Univ - Sci [Internet]. King Saud University; 2014;26(3):237-43. Available from: http://dx.doi. org/10.1016/j.jksus.2013.07.002; http://dx.doi.org/10.1016/j.jksus.2013.07.002

8. Mandal S, Patra A, Samanta A, Roy S, Mandal A, Mahapatra T Das, et al. Analysis of phytochemical profile of Terminalia arjuna bark extract with antioxidative and antimicrobial properties. Asian Pac J Trop Biomed. 2013;3(12):960-6. http:// dx.doi.org/10.1016/S2221-1691(13)60186-0

9. Mulla SK, Swamy P. Preliminary pharmacognostical and phytochemical evaluation of Portulaca quadrifida Linn. Int J PharmTech Res. 2010;2(3):1699-702.

10. Eberhardt TL, Li X, Shupe TF, Hse CY. Chinese tallow tree (sapium sebiferum) utilization: characterization of extractives and cell-wall chemistry. Wood Fiber Sci. 2007;39(2):319-24.

11. Houghton PJ, Hylands PJ, Mensah AY, Hensel A, Deters AM. In vitro tests and ethnopharmacological investigations: Wound healing as an example. J Ethnopharmacol. 2005;100(1-2):100-7. http://dx.doi.org/10.1016/j.jep.2005.07.001; PMid:16040217

12. Tsai CC, Lin CC. Anti-inflammatory effects of Taiwan folk medicine "Teng-Khia-U" 
on carrageenan- and adjuvant-induced paw edema in rats. J Ethnopharmacol. 1998;64(1):85-9. http://dx.doi.org/10.1016/S0378-8741(98)00108-1

13. Shetty S, Udupa S, Udupa L. Evaluation of antioxidant and wound healing effects of alcoholic and aqueous extract of Ocimum sanctum Linn in rats. Evidencebased Complement Altern Med. 2008;5(1):95-101. http://dx.doi.org/10.1093/ ecam/nem004; PMid:18317555 PMCid:PMC2249741

14. Yong YK, Tan JJ, Teh SS, Mah SH, Ee GCL, Chiong HS, et al. Clinacanthus nutans extracts are antioxidant with antiproliferative effect on cultured human cancer cell lines. Evidence-based Complement Altern Med. 2013;2013.

15. Hiradeve SM, Rangari VD. A review on pharmacology and toxicology of Elephan- topus scaber Linn. Sect Title Pharm. 2014;28(11):819-30.

16. Rothwell JA, Perez-Jimenez J, Neveu V, Medina-Rem??n A, M'Hiri N, Garc??aLobato P, et al. Phenol-Explorer 3.0: A major update of the Phenol-Explorer database to incorporate data on the effects of food processing on polyphenol content. Database. 2013;2013:1-8. http://dx.doi.org/10.1093/database/bat070 PMid:24103452 PMCid:PMC3792339

17. Markham KR. The Flavonoids [Internet]. Harborne JB, Mabry TJ, Mabry H, editors. Boston, MA: Springer US; 1975 [cited 2016 May 13]. pp 1-44. Available from: http://link.springer.com/10.1007/978-1-4899-2909-9. http://dx.doi.org/ 10.1007/978-1-4899-2909-9_1.

Cite this article : Aslam MS, Ahmad MS, Mamat AS. Phytochemical Evaluation of Polyherbal Formulation of Clinacanthus nutans and Elephantopus scaber to Identify Flavonoids. Pharmacognosy Journal. 2016;8(6):534-541. 